\title{
Povo de Deus uma sociedade contrastante: do movimento de Jesus à pós-modernidade
}

Orientadora: Ana Maria de Azeredo Lopes Tepedino

Mestrando: Marco Antonio Santos

Área de Concentração: Teologia Sistemático-Pastoral

Linha de Pesquisa: Religião e Modernidade

A igreja para continuar fiel a sua vocação pretendida por Cristo, precisa ser capaz de estabelecer conexões com a cultura e com o mundo no qual esta inserida em atitude dialógica. Como povo de Deus possuí identidade definida, contrastante é organismo vivo e pulsante que através dos séculos, penetrou em uma gama diversificada de culturas, como mediadora e sinal do reino porvir. Pensar a pós-modernidade como contexto possível para a vivência da eclesiologia de comunhão, é alinhar-se ao projeto salvífico de Deus para o mundo mantendo no tempo presente a igreja como voz que se faça ouvir, vida geradora de vida e luz para os povos cumprindo sua vocação em Cristo.

Palavras-chave: Movimento de Jesus; comunhão; igreja; sociedade contrastante, pós-modernidade. 